\title{
Zika Virus: A Current Public Health Challenge in India
}

\author{
Sonam Yangchen Bhutia \\ National Institute of Nursing Education, \\ PGIMER, Chandigarh, India
}

\begin{abstract}
Zika virus disease ( $\mathrm{ZiV})$, a mosquito borne re-emerging disease in India transmitted by a vector aedes with an agent flavivirus in Brazil 2015 has spread to various parts of the countries where WHO has declared it as a global health concern. India with a favourable climate and geographical location with increase distribution of aedes species can result into increase outbreak of Zika virus diseases along with malaria, japanese encephalitis, chikungunya, dengue and scrub typhus in the future. This review states on current global incidence of Zika, epidemiology, mode of transmission, clinical manifestations, complications, diagnosis, treatment and its preventive measures and the threats and challenges of Zika virus disease in India.
\end{abstract}

Keywords: Zika virus, aedes, mosquito, vector, microcephaly

\section{Introduction}

With an increase in globalization and urbanization, climate change has been one of the most daunting problem that human kind has ever encountered. Newly emerging and reemerging diseases are on the greater side which has spread over a distant geographical area due to the large movement of humans, animals or by transport through aviation and water etc. Many restricted microbial infection are crossing their geographical regions such as ebola virus, SARS, influenza virus etc. With an increase in global warming the global distribution of vectors are increasing, predominantly dengue, chikungunya, malaria are spreading on the higher side globally. ${ }^{[1]}$ Zika virus was largely unknown to the world till $20^{\text {th }}$ century, nestled in the shadow of apparently other severe mosquito borne virus infection like malaria, filiariasis, dengue etc. With the recent outbreak of Zika virus there has been an increasing life threatening complications occurring in the humans, as well as its rapid spread across the continents, the world is presently on high alert. The World Health Organization has declared Zika virus infection as a global concern.

\section{History of Zika virus}

It was in the year 1947, scientist researching on yellow fever in East African Virus Research Institute, Uganda extracted an agent known as Zika virus from a captive rhesus macaque in the Zika forest. ${ }^{[2]}$ Zika means overgrown in 'Uganda' language. ${ }^{[3]}$ In the year 1948, virus was rediscovered from mosquito species Aedes Africanus in the Zika forest. Subsequently there was a first human cases in Uganda and Tanzania in 1952. Thereafter in 1964, researchers identified the first proof that Zika virus causes disease in human. Next few decades virus has travelled to India, Indonesia, Malaysia and Pakistan where few human cases were reported with no outbreaks and disease. In 2007, there was a first large outbreak of Zika on the Island of Yap and subsequently virus has travelled to Pacific Islands causing outbreaks in Easter Island, the Cook Islands, New Caledonia and French Polynesia. It was on $7^{\text {th }}$ May 2015 Brazil was hit hardest by the Zika infection associated with neurological complications. ${ }^{[4]}$ WHO had announced a Public Health Emergency of International Concern in relation to the Zika virus. $^{[5]}$

\section{Incidence of Zika Virus Infection:}

As of WHO situational report on 2nd February 2017, 76 countries and territories have reported evidence of Zika virus transmission of which 59 has an outbreak reported from 2015 onwards, 7 countries is having possible endemic transmission in 2016 or 2017 and 10 countries with evidence of infection in or before 2015 . $^{[6]}$

\section{Epidemiology}

Agent- Zika Virus: Zika virus is a flavivirus and is a member of flaviviridae family. They are arthropod arbovirus. Like other flaviruus, Zika virus is enveloped and icosahedral and has a single stranded RNA virus. The incubation period of Zika infection is typically 3-12 days. It is spread by a bite of vector aedes mosquitoes, mainly Aedes aegypti and Aedes albopictus. ${ }^{[7]}$

Host- The host for Zika virus is human and animal. In the year 1947, rhesus macque placed in the cage of Zika forest developed fever and Zika virus was isolated in their samples. There was also an evidence of epizootic outbreak of Zika virus in Zika forest with first episode occurred in 1969 and second in 1970. First human cases was identified in Uganda in 1948 and thereafter a researcher working in the laboratory of Uganda fell ill from the virus and was identified as the first proof of Zika virus causing human disease. ${ }^{[4]}$ Zika virus has infected and caused disease in humans and non human primates(monkeys and apes). Infected human can act as a reservoir for Zika virus but there is no better evidence showing that 


\section{International Journal of Innovative Research in Medical Science (IJIRMS) \\ Volume 03 Issue 11 Nov 2018, ISSN: 2455-8737, Imp. Factor - 4.102 \\ Available online at $-\underline{w w w . i j i r m s . i n}$}

monkeys and apes to be a reservoir of Zika virus. Only few infected non human primates have shown the signs of illness in the milder form. ${ }^{[8]}$

Environment: Scientist has stated that Zika outbreak and the spread of infection could be due to the impact of climatic changes. The environmental changes are due to the manmade activities i.e. building dams, deforestation ultimately leading to global warming giving a greater impact on climate. It has been reported by NASA that 2016 year was recorded as the hottest year on earth. In addition, NASA data on global temperature analysis- 2015. Recife in Brazil had its hottest September, October and November on record i.e. about 1.2 degree Celsius above the normal.(38degree Celsius). Pernambuco state had its hottest and driest year since 1988, according to state weather agency. Globally 2015 was recorded as the warmest year on earth. ${ }^{[9]}$

Vector: The vector for Zika virus disease is aedes species of mosquitoes. ${ }^{[10]}$ Two type of female aedes species of mosquitoes has been infected with Zika virus namely African type i.e. Aedes aegypti and asian type i.e. Aedes albopictus. ${ }^{[11]}$ The virus has also been isolated from a arboreal species of mosquitoes in the Aedes genussuch as A. africanus, A. apicoargenteus, A. furcifer, A. hensii, A. luteocephalus and A. vittatus. ${ }^{[12]}$ Among the species of Aedes mosquitoes, A. aegypti is regarded as the global distributor as the virus is found across all the continents and has adapted to the colder northern climate. ${ }^{[11]}$

\section{Life cycle of Aedes mosquitoes}

The life cycle of aedes mosquitoes is $10-15$ days. The adult female Aedes mosquitoes feeds on human blood to lay their eggs. On average they produce 100- 200 eggs per batch. They can produce eggs up to five batch during a life time. After 2-3 days of feeding eggs are laid on damp surfaces in areas like tree holes and man -made containers like barrels, jars, buckets, pots, flower vase, tanks, tins, tyres, water cooler etc. Within 1- 48 hours the laid eggs are hatched and in 1- 3 days larvae develops and subsequently larvae develops into pupa within 6-8 days. Thereafter 1- 2 days after the pupal stage, a fully grown adult aedes mosquito develops. ${ }^{[13]}$

\section{Mode of transmission}

Zika virus infection is transmitted by a bite of an infected mosquitoes to human, mother to child via trans-placental transmission, sexual contact with an infected partner with zika virus and blood transfusion i.e. via transfusion of infected blood. ${ }^{[14]}$

\section{Mosquito bite}

Zika virus,arthropod borne virus infects and cause disease in human by the bite of an infected aedes species of mosquitoes. ${ }^{[15]}$ These species of are primarily day time bitters and can also spread dengue, chikungunya, Japanese encephalitis. Aedes aegypti mosquitoes are day time bitters and occupies urban areas with or without vegetation, live indoors and feeds directly on human blood and has highest vectorial capacity. Aedes albopictus lives in arboreal vegetation and are found mostly outdoors and feeds on humans as well as vertebrates. ${ }^{[16]}$
Aedes aegypti and Aedes albopictus are widely distributed throughout the subtropical and tropical parts in the world. Albopictus species is found in southern Europe, Northern China, Southern Brazil, Northern United States and Japan. ${ }^{[17]}$ In 1948, Zika virus was first taken from the mosquito Aedes africanus in Zika forest in Uganda. Thereafter in the year 1958, two more strains of virus was discovered. ${ }^{[4]}$ Aedes aegypti has a wider geographical distribution than Aedes albopictus and are found in the tropical and subtropical climates and is found in higher concentration in Southeast Asia including all of India and Brazil. ${ }^{[17]}$ More than 50 percent of world population are living in a arthropod disease risk area. ${ }^{[18]}$ In 1963, there was a first outbreak of dengue and chikungunya in Kolkota, India and thereafter many outbreaks were been reported from the different areas of the country and till 21 st century large number of people are being treated with different types of arthropod borne disease namely dengue, chickngunya, malaria every year. ${ }^{[19]}$ As Zika virus disease is spread by the vector Aedes mosquitoes, there is a high potentiality that the Aedes species of mosquitoes in India can spread Zika disease if it gets infected with an agent Zika virus.

\section{Non mosquito transmission}

\section{Transplacental transmission}

Foy D. Et.al conducted a study which stated that the two American scientist working in Senegal in 2008 on a mosquito sampling project, which was a Zika virus endemic area. Clinical and serological evidence indicated that both the scientist have contracted Zika virus infection, hemagglutination inhibition antibody titres and virus neutralizing titres were highly elevated for ZIKV and yellow fever virus. One of the person has transmitted the virus to his wife via sexual contact. The wife of a male traveller has never travelled to a Zika affected area, nor she came in contact with infected person and she tested positive for ZIKV infection. ${ }^{[20]}$

Another case report by Musso D. et.al on Tahiti patient in early December 2013, the patient had symptoms i.e. asthenia, low grade fever and arthralgia for 3 days followed by second episode after eight weeks. He came to seek for the treatment for hematospermia, and ZIKV was isolated from semen. This observation supported that ZIKV could be potentially be transmitted by sexual contact. ${ }^{[21]}$

Evidence has shown that ZIKV is transmitted through transplacental route. Mlakar J. Et. al case report study where a expectant mother ultrasonography report performed at 29 weeks of gestation revealed Microcephaly with calcifications in fetal brain and placenta. Feta autopsy revealed ZIKV infection was found in the fetal brain tissue on RT-PCR assay. ${ }^{[22]}$

\section{Clinical Manifestation of Zika Virus infection}

Many people infected with Zika virus are usually asymptomatic or will have milder symptoms. The most common symptoms are mild fever, arthralgia, myalgias, headache, maculopapular rash, conjunctivitis, malaise. The symptoms will last for several days to a week. Symptoms of the infection are similar to those of dengue and chikengunya. ${ }^{[23]}$

\section{Complication of Zika Virus infection}




\section{International Journal of Innovative Research in Medical Science (IJIRMS) Volume 03 Issue 11 Nov 2018, ISSN: 2455-8737, Imp. Factor - 4.102 \\ Available online at - $\underline{w w w . i j i r m s . i n}$}

Zika Virus infection during pregnancy has resulted into many birth defects. Investigators stated that risk of Microcephaly due to ZIKV infection in the first trimester was $0.95 \%$. Microcephaly is the most common complication of pregnancy related Zika virus infection. ${ }^{[24]}$ Till of 10th august 201615 countries have reported Microcephaly and other CNS malformations. ${ }^{[25]}$ Brazil reported the highest confirmed cases of Microcephaly in newborn from November 2015 to October 2016. ${ }^{[26]}$

A case report on Zika virus associated with Microcephaly by Mlakar J. et.al shown that ZIKV was found in the fetal brain tissue on reverse transcriptase polymerase chain reaction assay. Microscopic examination of the CNS revealed Microcephaly. ${ }^{[22]}$

Another case report on miscarriage associated with zika virus infection shown that a women who was 11 weeks pregnant showed no fetal heartbeat. The amniotic fluid, fetal and the placental tissue tested positive for ZIKV on RT- PCR assay and cell culture isolation. The lady had gone to northern Brazil for 3.5 week trip which is one of the Zika affected area and did not use any of the mosquitoes prophylaxis during her stay. ${ }^{[27]}$

Faccini L. et.a 1 has done a cohort of 35 infants with Microcephaly born during August- October 2015 in eight state of Brazil. The results revealed $25(71 \%)$ infants had severe Microcephaly and 17 (49\%) had one neurologic abnormality and among 27 infants who had neuro imaging studies, all had abnormalities. Tests for other congenital infections were negative. ${ }^{[28]}$ Other neurological complications include Guillain Barre Syndrome, meningitis, meningoencephalitis, myelitis. Till of 10th August 1016, 16 countries and territories have reported GBS and/ or laboratory confirmation of a Zika virus infection among GBS cases. ${ }^{[25]}$

Findings of case report on Zika virus infection complicated by Guillain Barre Syndrome, French Polynesia 2013. Retrospectively anamnestic data revealed that she had suffered from influenza like syndrome and her blood sample taken at eight and 28 days were positive for ZIKA specific IgM. ${ }^{[29]}$

\section{Opthalmic complications includes conjunctivitis, retinal atrophy}

Case study conducted by Furtado J, Esposito D, Klein. T, Pinto T, Fonseca B. et.al. on uveitis associated with Zika virus infection where a man in early 40's was diagnosed with Zika infection by RT- PCR assay of serum specimen. Aqueous humor in the clients right eye tested positive for ZIKV RNA by RT- PCR which shows that ZIKV related conjunctivitis may have intraocular inflammation. $^{[30]}$

\section{Adverse fetal outcomes}

The adverse effect on fetal outcome resulting from ZIKV infection is not yet proven, however there is an association linked between the maternal infection with Zika virus infection and the development of microcephaly in the infants. Microcephaly is a neuro developmental disorder in which occipito frontal circumference is below the third percentile for gestational age and sex. It may be congenital or it can develop in the first few years of life. Microcephaly results from a fetal brain disruption sequence, resulting into smaller head than the normal. This disorders results into intellectual disability, developmental delay, feeding problems, seizures, problems with movement and balance, hearing loss and vision problems. 31 Based on the systematic review of literatures WHO has stated that Zika virus infection is also one of the common cause of microcephaly.

In 2015, Brazil had a epidemic outbreak of Zika virus infection where 404 confirmed cases of microcephaly was reported since 22nd Oct 2015 to 30th Jan 2016. ${ }^{[25]}$ The adverse findings in Rio de Janerio report included fetal deaths, in utero growth restriction with or without microcephaly, ventricular calcifications, abnormal amniotic fluid volume or cerebral or umbilical artery flow. There has been a strong evidence linking Microcephaly to maternal exposure to Zika virus infection. ${ }^{[32]}$

\section{Diagnosis}

The diagnosis of Zika virus infection is done by the detection of viral nucleic acid by Reverse Transcriptase Polymerase Chain Reaction and IgM antibody detection test. The viral RNA can be identified in the serum during the first week of zika infection with RT-PCR. Since viremia decreases over time after 4-5 days, detection of RNA virus becomes difficult. Virus specific IgM antibodies may be detectable $\geq 4$ days after the onset of symptoms. There are major challenges when diagnosing the case because of cross reactivity of the IgM antibodies against other flaviviruses. In order to distinguish the type of flavivirus infection, plaque reduction neutralization tests is performed to measure virus specific neutralizing antibodies and determine the flavivirus reaction. For patient who have been vaccinated or had a natural immunity against the flavivirus in the past, even PNRT makes it difficult to identify the type of flavivirus causing illness. ${ }^{[33]}$

\section{Treatment for Zika Disease}

There is no vaccine available for Zika disease. Symptoms can be treatable by providing adequate rest, drinking more of fluids, taking medication such as acetaminophen or paracetamol to relieve fever and pain and avoiding aspirin and other NSAIDS. ${ }^{[34]}$

\section{Prevention of Zika Virus Infection}

As there is no specific treatment for the Zika virus infection, prevention and control measures are taken by eliminating the mosquito breeding sites, preventing mosquito bites using EPA registered insect repellents containing any of the active ingredients such as DEET, Picaridin, Bayrepel and Icaridin, OLE, PMD, IR3535. Caution has to be taken when using insect repellent on babies younger than 2 months old and one should not apply insect repellent onto the child's mouth, hands, eyes and cut or irritated area. Using mosquito nets, and treating the clothes with permethrin, wearing long sleeves and putting curtain on windows, repairing the broken windows, doors etc, and using insect killer helps is effective preventive way of protecting oneself and others from mosquito bites. ${ }^{[35]}$

When planning for a travel it is recommended that if a women is pregnant, one should avoid travelling to the Zika affected areas or check out the latest travel notice before planning for a trip. During the trip one should take the preventive measures to prevent the mosquito bites and after the trip one should protect from the 


\section{International Journal of Innovative Research in Medical Science (IJIRMS) Volume 03 Issue 11 Nov 2018, ISSN: 2455-8737, Imp. Factor - 4.102 \\ Available online at $-\underline{w w w . i j i r m s . i n}$}

mosquito bites and also the partner during sexual contact by using barrier method for 6 months after travel for men and 8 weeks for women and one should always consult a health care if one feels sick after returning from the trip. ${ }^{[35]}$ There are cases when one doesn't take the necessary precaution can result into the import of Zika infection. Fonseca $\mathrm{K}$ et. al. case report states that a woman who had travelled to Thailand visited a local hospital with fever and papular rash. PCR test revealed Zika virus infection. ${ }^{[36]}$ The first case of laboratory confirmed Zika virus infection imported to Europe through a German traveller returning from Zika affected area. Serological test revealed ZIKV specific neutralising antibodies in the blood. ${ }^{[37]}$ During December 2015- February 2016, 8 Israeli travellers were found positive with Zika virus infection where a total of $65.3 \%$ were diagnosed by RT- PCR, 95.7\% develop rash followed by fever and arthralgia, $53.1 \%$ with conjunctivitis. ${ }^{[38]}$ There has also been a report of ZIKV infection in a 24 year women living in Paris through a sexual contact with a man who had stayed in a Brazil since December 2015 to February 2016. Both the patient had developed acute fever, myalgia, arthalgia with pruritic rashes. Sample of urine and saliva was tested positive for ZIKV infection by RT PCR test. Therefore, it is very important to take necessary precaution to avoid the spread of Zika infection and one has to follow the necessary preventive measures. ${ }^{[39]}$

Regarding the blood transfusion, donor blood testing is always recommended. ${ }^{[40]}$ As most of the people who are affected with Zika doesn't show the signs and symptoms within a very first week. It is necessary to have a blood donor screening for identifying the affected individuals with Zika infection. Blood donation that tested positive for Zika virus to be removed from the supply. This can be made possible through State and local health departments and hospitals by their active participation in investigating the reports of potential disease in Zika affected regions.

\section{Zika virus infection - India}

India has a favourable climate and with increase in distribution of aedes species. Every year outbreak of vector borne diseases like malaria, Japanese encephalitis, chikungunya, dengue and scrub typhus are reported. As of 15th May 2017, the Ministry of Health and Family Welfare Government of India reported three laboratory confirmed cases of Zika virus in India. These cases were detected through a routine laboratory surveillance through RT-PCR test. Thereafter active cases of Zika virus transmission in India are reported. Cases of Zika virus disease has been reported in Jaipur, Rajasthan through ICMR survelliance system with more than 100 positive laboratory confirmed cases. Of the total, 23 were pregnant women ${ }^{[41]}$ Currently, India has been placed in Category -2 for Zika risk which is the second highest on a four point scale as per WHO (Feb 2018).

With an increase transmission of Zika infection internationally and a lack of immunity against such infection as well as with the current trend of the disease with its possible complications. The outbreak of the Zika virus disease can be more on the higher side posing a greater impact on health status of the population in future. Since, the trend of the disease is posing burden on the public health specialist in India. Hence, there is a need to create more awareness among the people living in the community. The Directorate
General of Health Services, Ministry of Health and Family Welfare advised on enhanced surveillance through community based surveillance, instructing Ministry Civil Aviation to follow recommended aircraft disinfection guidelines, preparing a rapid response team to investigate the suspected outbreak, having a laboratory diagnosis i.e. NCDC, Delhi and National Institute of Virology for detection of cases, communicating the risk among the clinicians and taking the appropriate measures by the government, following the guidelines of NVBDCP, deferring the travel to the affected countries and involving the NGOs, coordinating with international agencies, identifying research priorities and monitoring the present situation and changing the guidelines accordingly to the need. ${ }^{[42]}$ With increase threat of the Zika virus disease emphasis should be given on programmatic approach by bringing IEC activities in the community making the public aware by focusing more on its preventive aspects to tackle the burden of the diseases.

\section{Conclusion}

The ZIKV is a newly emerging disease where WHO had announced a Public Health Emergency of International Concern. The consequences of Zika virus infection results into congenital malformations and disability in newborn which can be one of the life threatening situation of the affected country. As the spread of the Zika virus can be unpredictable and India being the country infested with Aedes species so chances are high that the Zika infection can become pandemic. Therefore, it becomes an important to ensure that the guidelines for Zika prevention are being followed and also there is an urgent need in the field of research for developing the medicine and vaccine against Zika so that one can fight against it.

\section{References}

[1] Ramasamy R, Surendran SN. Global Climate Change and its Potential Impact on Disease Transmission by Salinity Tolerant Mosquito Vectors in Coastal Zones. Front Physiol. [serial online] 2012 Jan [cited 2016 November 10] 3:198. Available from: https://www.ncbi.nlm.nih.gov/pmc/articles/PMC3377959 I

[2] WHO. Emergencies. 2017. [online]. [cited 2016 October 24]: Available from: URL: http://www.who.int/emergencies/zika-virus/timeline/en/

[3] Wikipedia. Zika Forest. 2017. [online]. [cited 2017 February 10]: Available from: URL: https://en.wikipedia.org/wiki/Zika_Forest

[4] Medical Daily. A Brief History of Zika Virus, From its Discovery in the Zika Forest to the Global Outbreak Today. 2017. [cited 2017 April 3]: Available from: http://www.medicaldaily.com/zika-virus-outbreakhistory-381132

[5] WHO. Zika virus and complications: 2016 Public Health Emergency of International Concern. [online]. [cited 2016 November 10]: Available from: URL: http://www.who.int/emergencies/zika-virus/en/

[6] WHO. Emergencies Zika situation report. 2017. [cited 2017 March 2]: Available from: URL: http://www.who.int/emergencies/zika-virus/situationreport/2-february-2017/en/ 


\section{International Journal of Innovative Research in Medical Science (IJIRMS) Volume 03 Issue 11 Nov 2018, ISSN: 2455-8737, Imp. Factor - 4.102 Available online at $-\underline{w w w . i j i r m s . i n}$}

[7] Wikipedia. Zika Virus. 2017. [cited 2017 March 2]: Available from: URL: https://en.wikipedia.org/wiki/Zika_virus

[8] Centres for Disease Control and Prevention. Zika and Animals. 2016. [cited 2017 March 2]: Available from: URL: $\quad$ https://www.cdc.gov/zika/transmission/qaanimals.html

[9] NASA. 2016 Climate Trends Continue to Break Records. 2016. [cited 2016 July 24]: Available from: URL: https://www.cdc.gov/zika/transmission/qa-animals.html

[10] Wikipedia. Aedes aegypti. 2017. [cited 2017 June 8]: Available from: URL: https://en.wikipedia.org/wiki/Aedes_aegypti

[11] Kraemer UG M, Sinka E M, Duda A K, Mylne QN A, Shearer M F, Barker M C, Moore G C, Carvalho G R, Coelho E G, Bortel V W, Hendrickx G, Schaffner F, Elyazar RF I, Teng J H, Braddy J O, Messina P J, Pigott M D, Scott W T, Smith L D, Wint W GR, Golding N, Hay S. The global distribution of the arbovirus vectors Aedes asegypti and Ae. Albopictus. eLife. [serial online] 2015 Jun [cited 2016 September 18] 4:e08347. Available from:

https://www.ncbi.nlm.nih.gov/pmc/articles/PMC4493616 I

[12] Wikipedia. Zika Fever. 2017. [cited 2017 June 1]: Available from: URL: https://en.wikipedia.org/wiki/Zika_fever

[13] CDC. Life cycle:the mosquito. 2016. [cited 2016 May 25]: Available from: URL: https://www.cdc.gov/dengue/resources/factSheets/Mosqu itoLifecycleFINAL.pdf

[14] CDC. Zika Virus Transmission and Risk. 2017. [cited 2017 March 2]: Available from: URL: https://www.cdc.gov/zika/transmission/index.html

[15] Wikipedia. Arbovirus. 2017. [cited 2016 June 12]: Available from: URL: https://en.wikipedia.org/wiki/Arbovirus

[16] Aedes aegypti Aedes albopictus. [cited 2016 September 9]: Available from: URL: https://www.cdc.gov/dengue/resources/30jan2012/compa risondenguevectors.pdf

[17] Ecology, Epidemiology and Global Health. The global distribution of the arbovirus vectors Aedes aegypti and Ae. Albopictus. 2015. [cited 2016 June 28]: Available from: URL: https://elifesciences.org/articles/08347

[18] Palaniyandi M, Anand PH, Pavendar T. Environmental risk factors in relation to occurrence of vector borne disease epidemics: Remote sensing and GIS for rapid assessment, picturesque, and monitoring towards sustainable health. IJMR [serial online] 2017 April [cited 2017 June 1] 4(3):9-20. Available from: http://www.dipterajournal.com/pdf/2017/vol4issue3/Part A/4-2-12-428.pdf

[19] Sharma RS. Entomological Studies during Outbreak of Chikungunya in Marathwada Region of Maharashtra (India). Indmedica. [serial online] 2005 [cited 2016 October 8] 3(5):2006-11- 2006-12. Available from: http://www.indmedica.com/journals.php?journalid=3\&is sueid $=91 \&$ articleid $=1247 \&$ action $=$ article

[20] Foy BD, Kobylinski KC, Foy JL, Bradley J. Blitvich, Rosa AT, Haddow AD et.al. Probable Non-Vector-borne
Transmission of Zika Virus, Colorado, USA. Emerging Infectious Disease 2011 May 17(5): 880-882 http://www.ncbi.nlm.nih.gov/pmc/articles/PMC3321795/

[21] Musso D, Roche C, Robin E, Nhan T, Teissier A, Lormeau LM. Potential Sexual Transmission of Zika Virus. Emerging Infectious Disease 2015 Feb 21:2 https://wwwnc.cdc.gov/eid/article/21/2/pdfs/14-1363.pdf

[22] Mlakar J, Korva M, Tul N, Popovic M, Prijatelj MP, Mraz J et.al. Zika Virus Associated with Microcephaly. The New England Journal of Medicine 2016 March 374:951-958

http://www.nejm.org/doi/full/10.1056/NEJMoa1600651\# $\mathrm{t}=$ article

[23] WHO. Zika virus. 2016. [cited 2016 May 25]: Available from: URL: http://www.who.int/mediacentre/factsheets/zika/en/

[24] Johansson A M, Romero T M, Reefhuis J, Giboa M S, Hills L S. Zika and the Risk of Microcephaly. N Engl J Med. [serial online] 2016 July [cited 2016 September 10] 375(10):1-4. Available from: http://www.nejm.org/doi/full/10.1056/NEJMp1605367\#t $=$ article

[25] WHO. Zika situation report. 2016. [cited 2016 May 25]: Available from: URL: http://www.who.int/emergencies/zika-virus/situationreport/11-august-2016/en/

[26] Jaenisch T, Rosenberger D K, Brito C, Brady O, Brasil P, Marques E. Risk of Microcephaly after Zika virus infection in Brazil, 2015 to 2016. Bull World Health Organ. [serial online] 2016 May [cited 2016 July 15] 95(3):191-198. Available from: https://www.ncbi.nlm.nih.gov/pmc/articles/PMC5328112 I

[27] Wittenberg E, Saada A, Prosser LA, Woodaed GA, Encarnacion B, Peraza J, Hernandez BT, Motton J, Moore SM, Jones L, Alemi F. Miscarriage Associated with Zika infection. NEJM. [serial online] 2016 September [cited 2016 October 15] 374: 2142-51. Available from: http://www.nejm.org/doi/pdf/10.1056/NEJMc1605898

[28] Faccini LS, Ribeiro EM, Feitosa ML, Horovitz D, Cavalcanti D, Pessoa A et.al. Possible Association Between Zika Virus Infection and Microcephaly Brazil. Centers for Disease Control and Prevention 29, 2016 / 65(3);59-62 Available from http://www.cdc.gov/mmwr/volumes/65/wr/mm6503e2.ht $\mathrm{m}$

[29] Oehler E, Watrin L, Larre P, Goffart L, Lastere S, Valour F, Baudouiin L, Mallet H P, Musso D, Ghawche F. Zika Virus Infection Complicated By Guillain-Barré Syndrome - Case Report, French Polynesia, December 2013. Eurosurveillance. [serial online] 2014 March [cited 2016 July 10] 19(9). Available from: http://www.eurosurveillance.org/ViewArticle.aspx?Artic leId $=20720$

[30] Furtado JM, Esposito DL, Klein TM, Teixeira P T, Fonseca BA. Uveitis Associated with Zika Virus Infection. 2016. N Engl J Med. [serial online] 2016 July [cited 2016 October 3] 375(4):394-6. Available from: https://www.ncbi.nlm.nih.gov/pubmed/27332784?report $=$ abstract 
[31] Wikipedia. Microcephaly. 2016. [cited 2016 May 25]: Available from: URL: https://en.wikipedia.org/wiki/Microcephaly

[32] Brasil P, Pereira J, Moreira E, Nogueira R, Damasceno L, Wakimoto M, Rabello R, Valderramos S, Halai U, Salles T, Zin A, Horovitz D, Daltro P, Boechat M, Gabaglia C, Sequeira P, Pilotto J, Carrera R, Cunha DC, Carvalho L, Pone M, Siqueira AM, Calvet G, Baiao AE, Neves E, Carvalho P, Hausue R, Marschik P, Einspieler C, Janzen C, Cherry J, Filippis AM, Saines KN. Zika Virus Infection in Pregnant in Rio de Janeiro. NEJM [serial online] 2016 December [cited 2016 September 3] 19(9). Available from: http://www.nejm.org/doi/full/10.1056/NEJMoa1602412\# $\mathrm{t}=$ article

[33] CDC. Division of Vector Borne Diseases. 2016 [cited 2016 Feb 20]: Available from: URL: https://www.cdc.gov/zika/pdfs/denvchikvzikv-testingalgorithm.pdf

[34] CDC. Zika Virus Treatment. 2017. [cited 2017 June 10]: Available from: https://www.cdc.gov/zika/symptoms/treatment.html

[35] CDC. Zika Virus Prevention. 2017. [cited 2017 June 10]: Available from: https://www.cdc.gov/zika/prevention/index.html

[36] Fonesca K, Meatherall, Zarra D, Drebot M, Donald J, Pabbaraju K, Wong S, Webester P, Lindsay R, Teiller R. First Case of Zika Virus Infection in a Returning Canadian Traveler. Am J Trop Med Hyg. [serial online] 2014 November [cited 2016 September 10] 91(5): 10351038. Available from: https://www.ncbi.nlm.nih.gov/pmc/articles/PMC4228871 /
[37] Tappe D, Rissland J, Gabriel M, Emmerich P, Gunther S, Held G, Smola S, Chanasit JS. Eurosurveillance. [serial online] 2014 Jan [cited 2016 September 10] 19(4). Available from: http://www.eurosurveillance.org/ViewArticle.aspx?Artic leId $=20685$

[38] Meltzer E, Leshem E, Lustig Y, Gottesman G, Schwartz Eli. The American Journal of Medicine. [serial online] 2016 Oct [cited 2017 Feb 10] 19(4). Available from: http://amjmed.org/the-clinical-spectrum-of-zika-virus-inreturning-travelers/

[39] Ortenzio E, Matheron S, Lamballerie X, Hubert B, Piorkowski G, Maquart M, Descamps D, Damond F, Yazdanpanah Y. NEJM. [serial online] 2016 June [cited 2016 Sept 28] 374: 2195- 2198. Available from: http://www.nejm.org/doi/full/10.1056/NEJMc1604449\#t $=$ article

[40] CDC. Zika Virus. Transmission and Risk. 2017 [cited 2017 June 25]: Available from: URL: https://www.cdc.gov/zika/transmission/index.html

[41] The Economic Times. 2018. [cited 2018 October 30]: Available from: https://economictimes.indiatimes.com/news/politics-andnation/india-reports-80-zika-cases-22-pregnantwomen/articleshow/66259595.cms

[42] Ministry of Health and Family Welfare. Department of Health and Family Welfare. Government of India. National Guidelines for Zika virus disease. [cited 2017 June 10]: Available from: https://mohfw.gov.in/media/disease-alerts/nationalguidelines-zika-virus-disease 